\title{
Epididymal Cystadenoma
}

National Cancer Institute

\section{Source}

National Cancer Institute. Epididymal Cystadenoma. NCI Thesaurus. Code C162483.

A benign cystadenoma in the epididymal ducts. 